\title{
UTILIZATION OF SOCIAL MEDIA TO PROMOTE TRADEMARK AND SERVICES AND THEIR LEGAL PROTECTION
}

\author{
Aflah \\ Faculty of Law, Universitas Sumatera Utara \\ email:aflah@usu.ac.id
}

\begin{abstract}
$T$

echnological advancements continue to evolve all the time, it cannot be hindered and repressed. Thus, such advances must be directed for the good and welfare of human life, including the development of social media-which are currently offered in various forms. Many benefits can be obtained from social media, among others, as a means to promote trademarks and services from producers to consumers. Promotion of trademarks and services through social media provides convenience and benefits for producers, since it can save cost and time. However, advertisement by using social media also has impact on the trademark law in Indonesia. The widespread use of Internet in the trade sector has brought a lot of consequences on the protection of trademark. Owners of trademarks or services obtain legal protection after they are applied and officially registered. Registered trademark is currently protected by Law No. 20 of 2016 concerning Trademark and Geographical Indications.
\end{abstract}

Keywords: Trademark, social media, promotion

\section{Introduction}

The use of social media is linked to the increasing provision of the Internet networks. Internet is one of the technological advances in the communication field, in the form of electronic media that affect human life. Prior the availability of Internet network, people depend on electronic media, such as radio, telephone, telegram, and television. The internet network encourages the provision of various social media, which are offered to facilitate communication.

Social media are online media where users can easily participate, share and create contents, including blog, social network, wiki, forum, and virtual world. Blog, social network, and wiki are the most common form of social media used by people around the world. As an online medium, social media is also perceived to support social interaction in which the use of web-based technology has shifted communication into an interactive dialogue (https://web. facebook.com/notes/wishnu-rahardjo/pengertian-social-media-social-network-peran-sertafungsinya/10151963078035205/?_rdc=1\&_rdr)

The users of social media are able to initiate communication or interaction, to send message of text, image, audio or video, to share and to build a network. Currently, social media that are most commonly used are blog, wiki and social network (http://rocketmanajemen.com/ definisisosial-media/). The development of social media can also be exploited by the brand owners to directly promote their products of goods or service to the customers, even to conduct online buying and selling transaction.

The utilization of social media for brand promotion is related to the usage of a domain name. It serves to connect a person or legal entity that puts the information on the Internet with other users of internet services around the world. The goal is to facilitate a person or legal entity to convey the desired information to the users of Internet services. For the users of Internet service, the media is useful to find out the comprehensive and unlimited information available on the Internet based on their needs and desires. Since the Internet has been widely used by 
various circles of society, abbreviation (Generic Abbreviation) is internationally determined to facilitate the operation of domain name.

Domain name consists of two parts, namely organizational identity and identifier, which describe the type of organization, i.e. dot com (.com for commercial), dot-edu (.edu for education institutions), dot-gov (.gov for government agencies), dot-org (.org for organization), dot-mil (.mil for military) and dot-net (.net for network) (Asian Law Group, 2001).

The use of social media for the promotion of trademarks and services is not merely involved domain name. Nowadays, there are several other ways, including by making account of Facebook, Whatsapp, Line, Instagram, and Twitter. Such types of social media are extensively utilized to promote goods or services. Today, many kinds of social media have been widely used to improve products and services as well as to directly sell goods and services to consumers. However, producers or entrepreneurs, particularly those from SMEs and home industry, often overlook even tend to ignore the aspects of legal protection of the use and utilization of social media as a means of promotion and trade. This issue is linked to the lack of public knowledge concerning with the legal regulations. It became the background of this paper.

The discussion in this paper revealed the two problems. As for the issues discussed in this paper are as follows:

1. What are the benefits of social media as a means to promote trademark and services?

2. How does the legal protection of trademark and services use social media as a means of promotion?

\section{Roles and Functions of Social Media}

The development of social media increases rapidly since they provide many conveniences for human life. Everyone can communicate with others anytime and anywhere, within a country or across other parts of the world at the international scale. If previously people had to get connected via phone only to listen each other's voice, nowadays, they can communicate by facing each other hence they can know the precise condition and circumstances. The users of social media can access and use them through the Internet. The Internet network may run smoothly and quickly, although sometimes there is a slow access of internet network. Nevertheless, it can still be used by the users without any requirement for substantial fees, without expensive and self-made tools.

Social media have several features, among others are explicated as follows (https://web. facebook.com/notes/wishnu-rahardjo/pengertian-social-media-social-network-peran-sertafungsinya/10151963078035205/?_rdc=1\&_rdr):

1. Through social media, people can send messages and communicate not only to one person but it can convey messages to several people at once.

2. People can express any things freely and openly.

3. The messages can be carried out faster than using other media.

4. The recipient of the message can flexibly determine any time to interact and to respond the received message.

Aside from its function as information and communication tool, social media can also be used as an efficient and productive promotion and advertising medium since people throughout the world can access it. For home industry producers and SME's entrepreneurs, social media is one of the most effective methods to reach their customers wherever they live.

Social media has a role as an intermediary tool that connects an individual with another or a community group with another group, which is not limited by space and time to communicate, to have social contact and to share information in various forms and contents, including audio and motion picture, hence there is a dynamic social interaction. 
There are several advantages gained from recent social media, among others are as follows (https://web.facebook.com/notes/wishnu-rahardjo/pengertian-social-media-social-networkperan-serta-fungsinya/10151963078035205/?_rdc=1\&_rdr):

1. Social media have natural properties. They are easily to use, without any requirement of specific skills, high level skills or excellent management skills. They only need a unit of computer or a mobile phone (cellular) that has been equipped with various types of social media feature as well as internet connection.

2. Social media are where relationships are built. They offer an unparalleled opportunity for interaction between producers and customers. The company will get a direct feedback, idea, trial as well as manage the services quicker.

3. Through social media, goods and services can be provided globally. Therefore, any business can be advertised through various forms of information in a short time, regardless of its geographical location.

4. Social media is measurable. Through the provision of tracking system, messages can be identified easily, hence the number of activities that have been done every day can be known.

In accordance with the effectiveness and efficiency of social media, some positive functions of social media can be acquired. Based on the communication systems, social media function as a management and administrative system for individuals, corporations or legal entities, feature as a system of knowledge, education, and planning.

\section{Utilization of Social Media as a means to Promote Trademarks and Services}

Several benefits can be obtained from the use of social media as a means to promote and trade both goods and services. They are as follows:

\section{Save Cost and Save Time}

The rapid development of social media is supported by the availability of media for everyone. Compared with traditional media, such as television, radio, and newspaper, which require a significant capital and a lot of workforces, social media have its distinctive characteristics. The users of social media can access them with even slow network access, inexpensive fare, inexpensive tools, and self-practice without any employees. The users of social media can freely edit, add, modify various texts, images, videos, graphics, and other contents (https://web. facebook.com/notes/wishnu-rahardjo/pengertian-social-media-social-network-peran-sertafungsinya/10151963078035205/?_rdc=1\&_rdr).

The use of social media as a means to promote product/service is an advantageous alternative since the actors in micro, small and medium entrepreneurs (SMEs) can minimize the budget of promotional costs. Promotion through social media does not require a hefty fee. A computer or mobile phone and internet network are sufficient for the manufacturers or seller to advertise the produced goods or services to consumers by sharing pictures or video of products or services. Furthermore, they merely require uploading it on Facebook, Whatsapp, Line, Instagram and Twitter, which can be performed personally without the need of a lot of manpower. The time required for promotion through social media is also more effective in which in relatively a shorter time, customers can see the desired good/service and purchase it based on their keenness and budget by directly contacting the producers or sellers for further inquiries about the product.

Cost and time savings from the promotion of goods or services through social media have successfully cut the enormous costs that have been previously spent if the promotion is done based on conventional methods. Moreover, the conventional methods have higher risk of damage and higher budget for worker's salary. 


\section{Prevent the Distribution of Counterfeit Goods Using Trademark}

Promotion of goods or services through using social media also prevents the circulation of counterfeit goods by using well-known brand or trademark. This is because the producers and SMEs' entrepreneurs certainly reconsider if they want to promote the brand through social media by using brand/trademark that has been listed formerly. Nevertheless, it can cause legal problems, such as lawsuit and even trial from the owner of the registered brand for using the brand without any permission and the knowledge of the registered trademark owner. Essentially, it would be better if the promoted goods use their registered names.

The subject of a dispute or the basis of a lawsuit is mostly from the owner of registered trademark to the owner of another registered trademark because the similarity of pronunciation, word or writing of the trademark, known by the term of brand, which has "substantially" or "overall similarity" with the trademark of former goods or services (Aflah, 2017).

Promotion of the brand through social media also prevents the trading of counterfeit goods by using a well-known brand, because the producers, SMEs' entrepreneurs and the owners of home industries, will try to increase their level of confidence by registering trademark, goods and quality of offered services. Of course, they attempt to avoid conflict with outstanding registered brand/trademark.

Improvement of the quality of goods and services will continuously and undoubtedly have an impact on the increasing loyalty of customers. Therefore, customers will remain loyal to use the products or services.

\section{Increase Sales and Profits for Businessmen, SMEs and Home Industry}

Promotion through social media can increase sales and profits of producers in a faster way, since almost people from diverse group of age, namely children, adolescents, adults and even Elderly have been familiar with social media as a means of communication. Social media can gather both sellers and buyers despite of their distant locations. They can carry out buying and selling transactions through social media. The process of transaction through social media no longer requires an actual market. However, in such a transaction, both parties have to conduct it based on the principles of mutual trust.

Basically, goods promoted through social media are quickly recognized and acknowledged by the public since people can access them from their account of social media without having to leave their houses. Moreover, there are many options; people can choose the desired goods or services, even without having to pay for the shipping of products since most of producers provide free shipping.

Through social media, producers or sellers are able to directly advertise or promote goods and services, and the whole world can see them. The products and services are sold quickly, consumers are able to directly contact the seller, after the deal, the goods will be shipped to the customers in relatively a short time. Basically, both producers and sellers gain the benefits.

\section{Legal Protection for Trademark and Services in Social Media}

The advancement of information and communication technology has brought various impacts, both positive and negative ones. On the one hand, such advances contribute to the improvement of welfare and the development of human civilization. On the other hand, there is a leeway to violate the law. Information and communication technology has also changed the attitudes, behaviour and lifestyle of global society, caused the borderless world, and brought changes in various dimensions of life (https://yuokysurinda.wordpress.com/2016/03/ 08/ perlindungan-nama-domain-merek-di-internet/).

The use of social media as a means to promote trademark and services by business actors, both businessmen and SMEs' entrepreneurs, must pay attention to the aspects of legal protection. It is to ensure the use of social media as a means of promotion is protected by applicable law. 
At least, there are some laws and regulations related to the use of social media as a means of promotion, including Law No. 20 of 2016 concerning Trademark and Geographical Indication, Law No. 11 of 2008 concerning Electronic Information and Transactions, and Law No. 19 of 2008 on the Amendment to Law No. 11 of 2008 on Electronic Information and Transactions (IET Law).

According to Article 1, Paragraph (1) of Law No. 20 of 2016, Mark is a sign that may be displayed graphically are pictures, logos, names, words, letters, numbers, color arrangements, in the form of 2 (two) dimensions and/or 3 (three) dimensions, sounds, holograms, or a combination of aforementioned elements to distinguish goods and/or services produced by persons or legal entities in the goods and/or services trade activities.

Right of Mark is an exclusive right granted by the state to the owner of the registered trademark for a specified period for using the trademark or allowing other party to use it. According to Article 3 of the Law No. 20 of 2016, Right of Mark is obtained subsequent to the registration of Mark hereto.

The provision of the laws suggests that the state will only provide legal protection to registered trademarks. Similarly, brands or services promoted through social media will have legal protection after they are registered. Entrepreneurs of SMEs and home industries must apply and register their original trademarks, instead of imitating other well-known and registered trademarks, to advertise goods or services through social media. Moreover, the imitation can be deemed as the attempt to take personal advantage by deliberately deceiving costumers using famous brands or producing counterfeit goods which quality is not the same with the quality of the original products.

The application of trademark registration must be proposed by a good-faith applicant. This provision is stipulated in Article 21 paragraph (3) of Law No. 20 of 2016 that states Application shall be rejected if an Applicant with a bad faith files it. According to Article 83 of Law No. 20 of 2016, it is stated that:

1. The owner of a registered Mark and a registered Marking licensee may file a lawsuit against another person who unlawfully uses a Mark that has similarity in essence or its entirety for similar goods and/or services in the form of: Owner of a Registered mark and/ or the Licensee of registered Mark may file a law suit to the counter party who unrightfully utilizing a Mark which has similarity in its essential or its entirety for goods and/or service of the same kind, in a form of:

a. Damages law suit, and/or

b. Termination of all acts that related to the utilization of Mark hereto.

2. Lawsuit as stipulated by paragraph (1) shall be filed by an owner of a famous Mark based on a court decision.

To avoid a lawsuit from another party, before promoting a brand through social media, the business actors and the owners of SMEs and home industry must register their brands in advance to obtain legal protection and continually improve the quality of offered goods or services to customers, therefore it will support the loyalty of customers. Promotion of the brand through social media has a positive effect since the owners of unregistered brand will rethink if they want to promote their products on social media and attempt to avoid the claim from the owner of original brand if the similarity of the product is recognized. Promotion by uploading the brand through social media will be recognized by the reputable original brand, particularly those done by irresponsible parties.

In addition to the Trademark Act, Law No. 11 of 2008 on Information and Electronic Transactions has governed the ownership of domain names and their use. Article 23 of the IET Act explains that: 
1. Any state administrator, person, business entity, and/or the society shall be entitled to hold Domain Names on a first applicant principle basis.

2. Holding and use of Domain Names as intended by paragraph (1) must be on the basis of food faith, non-violation of fair business competition, and non-infringement of the rights of other persons.

3. Any state administrator, person, business entity, and/or the society damaged by other person's unauthorized use of Domain Names shall be entitled to lodge a claim for cancelling such Domain Names.

The promotion of a brand on social media must be initiated by registration as well as the good intention from the brand owners. The principle of good faith is related to honesty. The trade based on honesty will bring trust to customers, virtue lies in the presence or absence of good faith in producers and traders who involve in the distribution of goods and services to customers.

Good faith lies in the field of civil law, especially in the area of property law. Good faith is essentially associated with a person's deeds that are done naturally and sincerely, hence they are detached from any trickery and violation to other party, as well as the encouragement of mutual trust (Mariam Darus, 2014).

Based on the explanation, it can be claimed that the use of social media as a means to promote of trademarks and services must be accompanied with good faith, which should be done reasonably and adequately, not contain deception, not disturb and not harm others. In other words, the promoted brand is the rights of the owner of registered trademark thus other parties should not use it without any permission of the rightful owner. The action of counterfeit the trademark of famous brand for personal gain will surely bring harms to others.

According to Article 1338 of the Civil Code, the determination of the execution of the treaty is stipulated as follows, agreements shall be executed in good faith. In addition to implement the principle of good faith, the use of social media as a means of promotion should not violate ethics, morality, religion and public order. Prior to the promotion of trademark or service on social media, the display of images, video, words, colouring, sounds, colour combinations and writings shall be evaluated for not violating any ethics and modesty, morality, religion and public interest. It is done since it will be seen, read, and heard by people from diverse backgrounds of age, education, religion, occupation, and gender. Thus, the process of editing is required before the development of trademark and services on social media.

The law will provide legal protection against the brand promoted through social media to a registered mark whose registration is done in good faith and displayed on social media with aesthetic values, non-violation of the law, non-violation of ethics, politeness, morality, religion and public interest.

\section{Conclusion}

1. Social media have facilitated the promotion of product, trademark and services that provide benefits for business actors as well as SMEs and home industry's entrepreneurs. It is claimed as effective and efficient means of advertisement. Using social media as promotional tool is useful in terms of saving time and reducing costs that must be incurred, preventing the circulation and trading of counterfeit goods by popularizing a trademark, providing benefits, and increasing the number of sales of products and services promoted on social media.

2. Legal protection of trademarks and services promoted on social media is granted only to registered trademarks. According to Article 3 of Law No. 20 of 2016, the rights on trademark are obtained after it is registered. After the registration, the new certified brand has legal protection. Furthermore, although legal protection is provided for registered 
trademarks, the use of social media as a means to promote trademark and services by the business actors and the owners of SMEs and home industries shall remain in compliance with applicable laws and regulations. In addition, they shall not violate public order and public interest.

\section{References}

Aflah. (2017). Prevention Of Trade In Counterfeit Goods Using Well-Known Marks Through Good Faith Principle In The Perspective Of Islam, Makalah, disampaikan pada "at the $2^{\text {nd }}$ International Conference on Islamic Law in Indonesia, Faculty of Law, Andalas University, Padang, $7^{\text {th }}-9^{\text {th }}$ November.

Asian Law Group. (2001). Intellectual Property Rights (Elementary) - Indonesia Australia Specialised Training Project Phase II, Australia.

Darus, Mariam. (2014) Perkembangan Prinsip Itikad Baik Sebagai Asas Umum di Dalam Hukum Indonesia, "Orasi Ilmiah", Presented at Dies Natalis Fakultas Hukum Universitas Sumatera Utara yang ke-60, Medan, 11 Januari.

https://web.facebook.com/notes/wishnu-rahardjo/pengertian-social-media-social-networkperan-serta-fungsinya/10151963078035205/?_rdc=1\&_rdr.

https://yuokysurinda.wordpress.com/2016/03/08/perlindungan-nama-domain-merek-diinternet/.

http://rocketmanajemen.com/definisi-sosial-media/.

Republik Indonesia, Law No. 20 of 2016 on Trademark and Geographical Indication.

Republik Indonesia, Law No. 11 of 2008 on Information and Electronic Transactions and Act Number 19 of 2008 on Amendment to Act Number 11 Year 2008 on Information and Electronic Transactions.

Subekti, R., and R. Tjitrosudibio. (1999). Kitab Undang-Undang Hukum Perdata, Revised edition. Jakarta: PT. Pradnya Paramita. 